\title{
Low Interval Integer Data Type
}

National Cancer Institute

\section{Source}

National Cancer Institute. Low Interval Integer Data Type. NCI Thesaurus. Code C102858.

A data type comprised of a set of consecutive low valued integers of an ordered base data type. 